\title{
Research of attitudes of the students studying in schools of physical education and sport toward disabled kids
}

\author{
Huseyin OZTURK, Ugur ABAKAY \\ School of Physical Education and Sport, University of Gaziantep, Gaziantep, Turkey. \\ Address Correspondence to H. Ozturk, hozturk@gantep.edu.tr
}

\begin{abstract}
This is a scientific study to analyze the attitudes of the students studying in schools of physical education and sports toward disabled children. In total 202 students ( 99 women, 103 men) who have attended to faculty of Physical Education and Sports of Gaziantep University participated in the research. Attitude Scale for kids with mental disabilities developed by Süngü was used in order to get the data of the research. Descriptive statistics for analysis of the data, Mann Whitney U test for pair group and Kruskall Wallis analysis for multiple groups were applied. The results of the research have indicated that students in schools of physical education and sports have sympathetic feelings for disabled children and favorable opinions for these kids to attend in icebreaker activities and education programs. No difference between the attitudes of different age, sex or grade groups were observed. It has also showed that the students who had had work experiences with disabled children before had more fear. Besides, it proved that the sport educations with disabled children provide students to have more positive attitudes. It has been concluded that the ones who claimed to be able to work with disabled children had higher marks.

Keywords: Attitude, disabled children, physical education and sport.
\end{abstract}

\section{INTRODUCTION}

Physical Education and Sport Faculties are education institutions which aim to teach students general culture, teaching physical education in preschool, primary and secondary schools, the abilities to work in departments related to ministry of youth and sport, sport clubs and private sport business, organizations in tourism; to provide the conscious and qualifications to be trainer and sport manager and to identify society problems, look for solutions, contribute to country's economic, social and culture.

Physical education and sport faculties have different branch in itself. These departments are coaching training, physical education and sport teaching, sport management and recreation. In all of these branches, there's sport education about disabled ones so that the students may work with disabled people thanks to the education which they have.

Attitude is a variance that is reflected behaviorally by observable and unobservable psychological factors such as intelligence and motive (7). Focusing on how attitudes change and develop, it can be determined that the society effects and cognitive structure periods on attitudes and the way it effects on attitudes (8).

Attitude is seen to be one of the most important factors that effect on motivation and behavior (18). Attitude can be also said to be the mixture of the process of motivational, emotional, perceptive and cognitive which an individual has against a case (11).

Attitudes cannot be gained inborn. It is later provided by learning. Relations in personal life such as parents, friends, communication devices and environment are some of the important factors that take an important role to affect the attitudes and the attitudes that we learn may possibly change (1). As well as attitude is an ability that is learnt, it directs one's behaviors and affects the decision period (22).

Gürsel (9) suggests that students of the universities should have physical education and sport classes for disabled people so that the students may not get the wrong information about disabled people but positive attitude and they may not get difficulty when they encounter in management department or sports of disabled ones.

It is quite important to carry out integration programs to help children with disabilities integrate 
with society and have the skills to live independent. Since education in different schools is against the human rights, integration programs have been more preferably than the education in different private schools. Therefore, these children can adapt the society in an easier way and they can get better education with the normal regulation (10).

For helping disabled people integrate with the society, it's a need to provide educational sources, supportive private lessons (2). In addition to this, the program and education applied and the way the teacher who applies the program should be also successful to improve the children with disabilities their cognitive, affective, social and psychomotor skills (14).

Expectations and attitudes of the ones who do not have disability are important during the education of disabled people. Negative attitudes toward disabled people make them have difficulties in handling the handicaps in their education and social lives. According to the fact that sport is considerably essential for the education of disabled people, the students who study related to physical and sport education should get the necessary information to have sympathy and empathy in order to help disabled people succeed (20).

This study was aimed to determine the attitudes of the students who study in physical and sport education toward children with disabilities. At this point, following the questions was asked:

The students of Department of Physical Education and Sports;

1. How are the attitudes toward children with disabilities?

2. Do the attitudes toward disabled children change according to the difference of sex?

3. Do the attitudes toward disabled children change according to the difference of age?

4. Do the attitudes toward disabled children change according to the difference of classes?

5. Do the attitudes toward the disabled children change according to the experiences with studying with disabled children before?

6. Do the attitudes toward disabled children change in terms of taking sport classes with disabilities?

7. Do the attitudes toward disabled children change in terms of asking for studying with disabilities?

\section{MATERIAL \& METHOD}

Population Sample: The population consists of the students who attend to Physical Education and Sports in Gaziantep University during the education year 2013-2014.

The sample group consists of 202 students (99 women and 103 men). The sample group's personal characteristics are shown in Table 1.

Table 1 shows above demonstrate the answers of the personal questions of the groups. According to this, 99 women (49\%), 103 men (51\%), most of them are seen to be between at 20-24 aged and also a lot of applicants that are at almost same levels are seen. Considering the questions about the disabled people, most $(76.2 \%)$ are observed not to have had experience with disabled and most again (76.7\%) are observed not to have taken any lessons about the disabled and most $(64.9 \%)$ are seen to claim that they would like to work with disabled children.

Table 1. Personal characteristics of the group ( $n=202)$.

\begin{tabular}{|c|c|c|c|}
\hline Variance & Groups & $\mathrm{n}$ & $\%$ \\
\hline \multirow[t]{2}{*}{ Sex } & Men & 103 & 49.0 \\
\hline & Women & 99 & 51.0 \\
\hline \multirow[t]{4}{*}{ Age } & 15-19 age & 21 & 10.4 \\
\hline & $20-24$ age & 140 & 69.3 \\
\hline & $25-29$ age & 34 & 16.8 \\
\hline & 30 age + & 7 & 3.5 \\
\hline \multirow[t]{4}{*}{ Class } & 1.class & 57 & 28.2 \\
\hline & 2.class & 48 & 23.8 \\
\hline & 3.class & 51 & 25.2 \\
\hline & 4.class & 46 & 22.5 \\
\hline \multirow{2}{*}{$\begin{array}{l}\text { Have you ever had a studying experienc } \\
\text { with disabilities? }\end{array}$} & Yes & 48 & 23.8 \\
\hline & No & 154 & 76.2 \\
\hline \multirow{2}{*}{$\begin{array}{l}\text { Have you ever had a class about } \\
\text { disabled children? }\end{array}$} & Yes & 47 & 23.3 \\
\hline & No & 155 & 76.7 \\
\hline \multirow{2}{*}{$\begin{array}{l}\text { Would you like to work with disabled } \\
\text { children in a private education school } \\
\text { or class? }\end{array}$} & Yes & 131 & 64.9 \\
\hline & No & 71 & 35.1 \\
\hline
\end{tabular}

Data acquiring methods: Personal information form and Attitude Scale toward Disabled Children made by Süngü (2012) which can be also seen below are used to acquire the data of the research. In this first section, 6 questions of personal information form related to aim of research prepared by research groups and in the second section; Attitude Scale toward Disabled Children are used. The general Croncbach alpha value is 0.75 for this study. The scale consists of 21 questions and likert scale and 
five sub-dimensions: Benefits (0.70), emotions (0.67), supports (0.69), acceptance (.71) and fears (.86).

Data analysis: Data acquired by scales used are used to analyze the statistical results by benefiting the software SPSS 16.0. Kolmogrov-Smirnov and Shapiro-Wilk normality tests have been used to find out whether the data of the research have a regular rage or not. . For the data which does not demonstrate regular rage, Kurtosis-Skewness values are checked and finally seen that data does not give the regular rage as they are not between \pm 2 . In analysis of data, descriptive statistics and in pair groups, Mann Whitney $U$ test and in multiple groups, Kruskall Wallis tests are used.

\section{RESULTS}

Table 2 shows the average acquired by research groups' attitude scale scores. According to this, the highest average $(X=2.33)$ is seen on fears subdimensions.

Table 3 shows that Kruskal Wallis test applied to determine whether different of attitudes in terms of age variance have been seen or not and according to this, no difference between the groups in terms of age has been found $(\mathrm{p}>0.05)$.

Table 2. Average that is acquired by sub-dimensions of the attitude scale.

\begin{tabular}{lcc}
\hline & Average & SD \\
\hline Benefits & & \\
Emotions & 4.24 & 0.76 \\
Supports & 3.88 & 0.99 \\
Acceptance & 3.57 & 0.91 \\
Fears & 3.38 & 0.92 \\
& 2.33 & 0.99 \\
\hline
\end{tabular}

Table 4 shows that Mann Whitney $U$ test applied to determine whether differences of attitudes in terms of gender variance have been found and according to this no difference has been found between the classes ( $p>0.05)$.

Table 5 shows that Kruskal Wallis test applied to determine whether differences have been found in terms of the research group's variance class and according to this, no difference has been found between the classes in terms of class variance $(\mathrm{p}>0.05)$.

Table 3. Comparison of the attitudes of the research groups in terms of age variance.

\begin{tabular}{|c|c|c|c|c|c|c|}
\hline Sub-dimensions & Groups & $\mathrm{n}$ & Mean Rank & $\mathrm{df}$ & $X^{2}$ & $\mathrm{p}$ \\
\hline \multirow[t]{4}{*}{ Benefits } & $15-19$ age & 21 & 89.45 & 3 & 2.354 & .502 \\
\hline & $20-24$ age & 140 & 105.33 & & & \\
\hline & $25-29$ age & 34 & 96.75 & & & \\
\hline & 30 age + & 7 & 84.07 & & & \\
\hline \multirow[t]{4}{*}{ Emotions } & $15-19$ age & 21 & 95.40 & 3 & 4.097 & .251 \\
\hline & $20-24$ age & 140 & 105.59 & & & \\
\hline & $25-29$ age & 34 & 96.03 & & & \\
\hline & 30 age + & 7 & 64.50 & & & \\
\hline \multirow[t]{4}{*}{ Supports } & $15-19$ age & 21 & 108.67 & 3 & 4.897 & .179 \\
\hline & $20-24$ age & 140 & 103.17 & & & \\
\hline & 25-29 age & 34 & 99.71 & & & \\
\hline & 30 age + & 7 & 55.36 & & & \\
\hline \multirow[t]{4}{*}{ Acceptance } & $15-19$ age & 21 & 111.60 & 3 & 1.035 & .793 \\
\hline & $20-24$ age & 140 & 101.56 & & & \\
\hline & $25-29$ age & 34 & 97.04 & & & \\
\hline & 30 age + & 7 & 91.71 & & & \\
\hline \multirow[t]{4}{*}{ Fears } & $15-19$ age & 21 & 91.52 & 3 & .814 & .846 \\
\hline & $20-24$ age & 140 & 103.21 & & & \\
\hline & 25-29 age & 34 & 101.74 & & & \\
\hline & 30 age + & 7 & 96.07 & & & \\
\hline
\end{tabular}


Table 4. Comparison of the attitudes of the research group in terms of gender variance.

\begin{tabular}{llccccc}
\hline Sub-dimensions & Groups & $\mathrm{n}$ & Mean Rank & Sum of Ranks & $\mathrm{U}$ & $\mathrm{p}$ \\
\hline \multirow{2}{*}{ Benefits } & Woman & 99 & 102.07 & 10104.50 & 5042.5 & .892 \\
& Man & 103 & 100.96 & 10398.50 & & \\
Emotions & Woman & 99 & 102.39 & 10137.00 & 5010.0 & .830 \\
& Man & 103 & 100.64 & 10366.00 & & \\
Supports & Woman & 99 & 95.45 & 9449.50 & 4499.5 & .146 \\
& Men & 103 & 107.32 & 11053.50 & & \\
Acceptance & Woman & 99 & 95.47 & 9451.50 & 4501.5 & .148 \\
& Man & 103 & 107.30 & 11051.50 & & \\
& Womars & 99 & 98.94 & 9795.50 & 4845.5 & .537 \\
& Man & 103 & 103.96 & 10707.50 & & \\
\hline
\end{tabular}

Table 5. Comparison of attitudes of research groups in terms of class variance.

\begin{tabular}{|c|c|c|c|c|c|c|}
\hline Sub-dimensions & Groups & $\mathrm{n}$ & Mean Rank & $\mathrm{df}$ & $X^{2}$ & $\mathrm{p}$ \\
\hline \multirow[t]{4}{*}{ Benefits } & 1.class & 57 & 104.74 & 3 & 5.332 & .149 \\
\hline & 2.class & 48 & 84.98 & & & \\
\hline & 3.class & 51 & 110.13 & & & \\
\hline & 4.class & 46 & 105.16 & & & \\
\hline \multirow[t]{4}{*}{ Emotions } & 1.class & 57 & 103.49 & 3 & 4.092 & .252 \\
\hline & 2.class & 48 & 97.65 & & & \\
\hline & 3.class & 51 & 91.36 & & & \\
\hline & 4.class & 46 & 114.29 & & & \\
\hline \multirow[t]{4}{*}{ Supports } & 1.class & 57 & 97.03 & 3 & 6.493 & .090 \\
\hline & 2.class & 48 & 90.41 & & & \\
\hline & 3.class & 51 & 100.77 & & & \\
\hline & 4.class & 46 & 119.42 & & & \\
\hline \multirow[t]{4}{*}{ Acceptance } & 1.class & 57 & 105.35 & 3 & .595 & .898 \\
\hline & 2.class & 48 & 99.55 & & & \\
\hline & 3.class & 51 & 102.95 & & & \\
\hline & 4.class & 46 & 97.15 & & & \\
\hline \multirow[t]{4}{*}{ Fears } & 1.class & 57 & 93.07 & 3 & 4.779 & .189 \\
\hline & 2.class & 48 & 111.18 & & & \\
\hline & 3.class & 51 & 93.40 & & & \\
\hline & 4.class & 46 & 110.83 & & & \\
\hline
\end{tabular}

Table 6 shows that the Mann Whitney U test applied to determine whether the attitudes of the research group in terms of their experience of working with disabled children and according to this, differences have been seen on sub-dimensions of fears except for the four sub-dimensions $(p<0.05)$. Considering average, the ones who have experiences have been seen to have higher grades.

Table 7 shows that the Mann Whitney U test applied to determine whether the attitudes of the research group in terms of taking disabled sport lessons change and according to this, differences have been seen on sub-dimensions of supports in terms of taking disabled sport lessons variance $(p>0.05)$. Those who take are seen to have higher grades than the ones who do not.

Table 8 shows the Mann Whitney $U$ test applied to determine whether the attitudes of the research group in terms of wanting to work with disabled children change and according to this, differences have been seen on sub-dimension of emotions, fears and acceptance $(\mathrm{p}<0.05)$. Those who say yes on each scale are seen to have higher average. 
Table 6. Comparison of attitudes of the research group in terms of having experience with disabled children.

\begin{tabular}{llccccc}
\hline Sub-dimensions & Groups & $\mathrm{n}$ & Mean Rank & Sum of Ranks & $\mathrm{U}$ & $\mathrm{p}$ \\
\hline \multirow{3}{*}{ Benefits } & Yes & 48 & 100.61 & 4829.50 & & \\
& No & 154 & 101.78 & 15673.50 & 3653.500 & .904 \\
Emotions & Yes & 48 & 105.95 & 5085.50 & & \\
& No & 154 & 100.11 & 15417.50 & 3482.500 & .542 \\
Supports & Yes & 48 & 113.45 & 5445.50 & & \\
& No & 154 & 97.78 & 15057.50 & 3122.500 & .102 \\
Acceptance & Yes & 48 & 96.16 & 4615.50 & & \\
& No & 154 & 103.17 & 15887.50 & 3439.500 & .465 \\
Fears & Yes & 48 & 118.14 & 5670.50 & & \\
& No & 154 & 96.31 & 14832.50 & 2897.500 & .022 \\
\end{tabular}

Table 7. Comparison of attitudes of the research group in terms of taking disabled sport lesson.

\begin{tabular}{llccccc}
\hline Sub-dimensions & Groups & $\mathrm{n}$ & Mean Rank & Sum of Ranks & $\mathrm{U}$ & $\mathrm{p}$ \\
\hline \multirow{2}{*}{ Benefits } & & & & & & \\
& Yes & 47 & 106.55 & 5008.00 & 3405.000 & .497 \\
Emotions & No & 155 & 99.97 & 15495.00 & & \\
& Yes & 47 & 111.97 & 5262.50 & 3150.500 & .157 \\
Supports & No & 155 & 98.33 & 15240.50 & & \\
& Yes & 47 & 118.39 & 5564.50 & 2848.500 & .023 \\
Acceptance & No & 155 & 96.38 & 14938.50 & & .394 \\
& Yes & 47 & 95.18 & 4473.50 & 3345.500 & \\
Fears & No & 155 & 103.42 & 16029.50 & & .321 \\
& Yes & 47 & 108.81 & 5114.00 & 3299.000 & \\
\end{tabular}

Table 8. Comparison of attitudes of the research group in terms of wanting to work with disabled people.

\begin{tabular}{llccccc}
\hline Sub-dimension & Groups & $\mathrm{n}$ & Mean Rank & Sum of Ranks & $\mathrm{U}$ & $\mathrm{p}$ \\
\hline \multirow{3}{*}{ Benefits } & & & & & & \\
& Yes & 131 & 115.30 & 15104.00 & 2843.000 & .000 \\
Emotions & No & 71 & 76.04 & 5399.00 & & \\
\multirow{3}{*}{ Supports } & Yes & 131 & 116.55 & 15268.00 & 2679.000 & .000 \\
& No & 71 & 73.73 & 5235.00 & & \\
Fears & Yes & 131 & 108.01 & 14149.00 & 3798.000 & .030 \\
& No & 71 & 89.49 & 6354.00 & & \\
Acceptance & Yes & 131 & 108.93 & 14270.00 & 3677.000 & .013 \\
& No & 71 & 87.79 & 6233.00 & & \\
& Yes & 131 & 102.07 & 13371.50 & 4575.500 & .848 \\
\hline
\end{tabular}

\section{DISCUSSION}

In this part of the research, the results have been evaluated. The argument of the point average acquired from attitude scale and meaningful differences acquired from comparison of the variances has been given. Considering the point average acquired from attitude scale of research group, it has been seen that the highest average is $(X=4.24)$ on benefits sub-dimension and the lowest average is $(X=2.33)$ on fears sub-dimension. The average in the original study by Süngü (20) has parallels with our researches (Benefits $X=4.0$, Fears 
$X=2.67)$. With reference to these facts, it can be said that the students studying in physical education and sports have positive feelings toward the disabled children.

No difference between the group's attitudes according the different age and sex was found. (Table 3 and 4). Only in the original study for the students in physical education and sports made by Süngü (20), some results in men's favor on acceptance sub-dimension was found. Downs \& Williams (6), Lyons \& Hayes (12) claimed that there were significant differences in women's favor about the attitudes of the students of physical education and the sports.

Different results in body of literature in terms of variance of gender were found. In this regard, more studies are required to clearly define the effect of gender on attitudes toward children with mental disabilities.

There has not been statistically significant difference on attitude sub-dimension in terms of class variance of the research (Table 5). In the research which was done by Buell et al. (3) in private departments of the universities, first and third grade students' attitudes toward the disabled people were observed and third grade students were found to be more positive. In another research made by Rizzo \&Kirkendall (16) to observe the physical education and sports teachers' attitudes toward disabled students, the points of first grade students' attitudes toward disabled people were resulted to be lower. That different results faced in the researches and no difference in our studies has shown that it cannot be said a definite conclusion about the attitudes of students studying in physical education and sports toward disabled people in terms of class variance.

Considering the comparison of the scores acquired by attitude scales in regard to the research group's experiences of studying with disabled people, it was seen that the ones who had already experiences had higher scores on fears subdimension (Table 6). This result may be caused by the consciousness of the experienced students about the difficulties of education process.

In a study conducted by Özer et al. (13), the state of having a disabled student was seen to be not very effective factor on attitude of physical education teachers. Rizzo \&Kirkendall (16) have indicated that the attitudes of physical education teachers who have disabled students have no difference.
A reasonable difference has been found on supportive sub-dimension of the research group in terms of taking sport classes (Table 7). The students who have taken sport with disabilities classes have been seen to be more positive on supportive dimension. It is known that taking sport classes with disabled people provides the students' attitudes toward disabled people more positive feelings $(4,17,19)$. Donaldson $(5)$ has observed in one of his research that there was a difference between the comparison of the students who have optional sport classes with disabled people and the students who do not.

In the research of teachers' attitudes toward children with mental disabilities which was conducted by Papadopoulouet al. (15), a reasonable relation was observed between teacher's attitudes and the education that they took. Tait\&Purdie (21) have claimed that the attitudes of teachers who took lessons about the disabled individuals have been seen to be more positive.

In the study made by Gürsel (9), the physical education and sports lessons for disabled people given in the department has been determined to create a positive effect on changing the student's attitudes. Hence, it can be said that all the teachers who have opportunity to work with disabled children should take informative education about the disabled individuals to make a significant contribution to their attitudes. Some differences were found on other sub-dimensions except for the fear dimension of the attitude scale in terms of the research groups wanting to work with disabled children. The attitudes of those who want to work in the four sub-dimensions were concluded to be more positive.

As a result; it has been resulted that the students who study in physical education and sports department of the university have good attitudes toward the children with disabilities and have positive feelings for those disabled children to participate in icebreaker and integration programs. No difference has been found in terms of age, gender or class of the research groups. It has been seen that the ones who worked with disabled children before have had more fear. It is also now determined that students taking disabled sport classes provides them to have more positive attitudes. Attitudes of those who have claimed to be able to work with disabled children have been seen to have higher grades. 


\section{REFERENCES}

1. Aydın O. Davranış Bilimine Giriş-4, 3. Baskı, Eskişehir: Anadolu Üniversitesi Açık Öğretim Fakültesi Yayınları, 1985.

2. Batu S, Kırcaali-İftar GK, Uzuner Y. Özel gereksinimli öğrencilerin kaynaştirildiği bir kiz meslek lisesindek öğretmenlerin kaynaştirmaya ilişkin görüş ve önerileri. Ankara Üniversitesi Eğitim Bilimleri Fakültesi Özel Eğitim Dergisi, 2004; 5(2):33-50.

3. Buell MJ, Halam R, Gamel-McCormick M, Scheer S. A survey of general and special education teacher's perceptions an inservice needs concerning inclusion. International Journal of Disability Development and Education, 1999; 46(2):143-156.

4. Craig CS. Labels and the Attitudes of undergraduate physical education students toward disabled individuals. Physical Educator, 1991; 48(3):142-146.

5. Donaldson J. Changing attitudes toward handicapped persons: A review and analysis of research. Exceptional Children, 1980; 46(7):504-514.

6. Downs P. Williams T. Student attitudes toward integration of people with disabilities in activity settings: a European comparison. Adapted Physical Activity Quarterly, 1994; 11:32-43.

7. Erkuş A. Psikometri Üzerine Yazılar, 1. Baskı, Ankara: Türk Psikologlar Derneği Yayınları, 2003.

8. Freedman JL, Sears DO, Carlsmith JM. Sosyal Psikoloji, Çev: Ali Dönmez, 4. Baskı, Ankara: İmge Kitabevi, 2003.

9. Gürsel F. "Physical education and sports for the disabled" course and students' attitudes. Hacettepe Üniversity Journal of Education, 2006; 31:67-73.

10. Kırcaali-İftar G. Kaynaştırma ve Destek Özel Eğitim Hizmetleri. Ed.; S. Eripek, Anadolu Üniversitesi Yayını, Özel Eğitim, 1998; 1018:17-22.

11. Krech D, Cructhfield RS. Sosyal Psikoloji: Teorive Problemler, Çev: Erol Güngör, 3. Baskı, İstanbul: Ötüken Yayınları, 1980.

12. Lyons M, Hayes R. Student perceptions of persons with psychiatric and other disorders. American Journal of Occupational Therapy, 1993;47:541-548.
13. Özer D, Nalbant $S$, Ağlamış CE, Baran F, Kaya Samut $P$, Aktop A, Hutzler Y. Physical education teachers' attitudes towards children with intellectual disability: The impact of time in-service, gender and previous acquaintance. Journal of Intellectual Disability Research, 2013; 57:1001-1013.

14.Özyürek M. Engelli Kişilere Yönelik Değiştirilen Tutumların Sürekliliği, Ankara: Gazi Üniversitesi Yayınları, 1995.

15.Papadopoulou D, Kokaridas D, Papanikolaou Z, Patsiaouras A. Attitudes of Greek Physical Education Teachers Toward Inclusion of Students With Disabilities, University of Thessaly, Greece, 2004.

16. Rizzo TL, Kirkendall DR. Teaching students with mild disabilities: What affects attitudes of future physical educators? Adapted Physical Activity Quarterly, 1995; 12: 205-216.

17. Rowe J, Stutts RM. Effects of practicum type, experience, and gender on attitudes of undergraduate physical education majors toward disabled persons. Adapted Physical Activity Quarterly, 1987; 4:268-277.

18. Sherif M, Sherif CW. Sosyal Psikolojiye Giriş II, Çev: M.Atakay, A.Yılmaz, İstanbul: Sosyal Yayınlar, 1996.

19.Stewart CC. Effects of practicum types in preservice adapted physical education curriculum on attitudes toward disable populations. Journal of Teaching in Physical Education, 1990; 10: 76-83.

20.Süngü B. Development and validation of the pre-service physical education and sport teachers' attitudes toward children with intellectual disabilities. Master Thesis. Çanakkale Onsekiz Mart Üniversity Healt Sciences İnstitute, Çanakkale, 2012.

21.Tait K, Purdie N. Attitudes toward disability: teacher education for inclusive environments. International Journal of Disability, Development and Education, 2000; 47(1):25-38.

22.Ülgen G. Eğitim Psikolojisi. İstanbul: Alkım Yayınları, 1997. 